\section{New mutual funds signal healthy state of high technology stocks}

\section{Washington}

BIOTECHNOLOGY stocks are, in the main, thriving (see below), and further proof of healthy market interest in science and technology stocks was provided at the beginning of the month by the launching of twin mutual funds which intend to invest in science and technology companies around the world. The funds, Sci/Tech Holdings Inc and Sci/Tech SA are notable for two reasons: the vast size of their operations and a novel plan to recruit leading scientists to an international scientific advisory council.

The funds started operating on 1 April with total net assets of $\$ 835$ million, the biggest sum of money ever in an initial public offering for the mutual fund industry. Sci/Tech Holdings Inc will be open to investors in the United States and Canada, Sci/Tech SA to investors elsewhere. Both funds will be managed

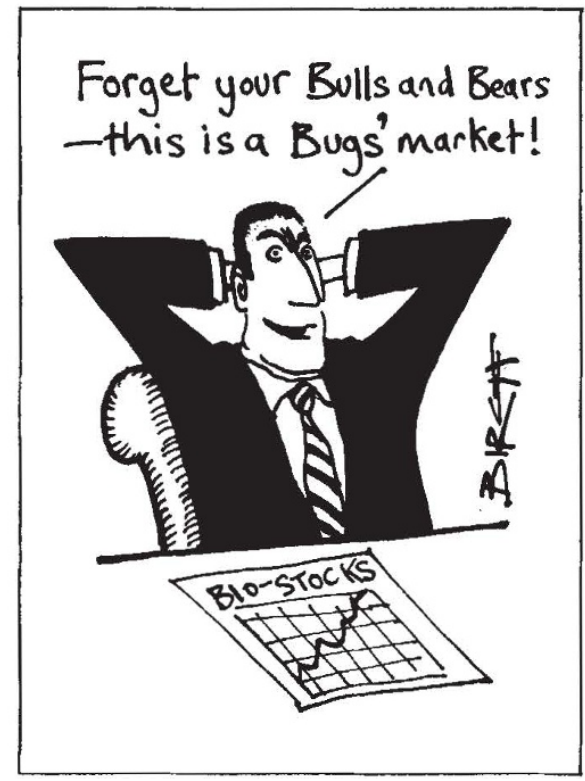

jointly by Merrill Lynch in New York, Lombard Odier in London and Nomura Capital Management in Tokyo.

A nine-member scientific advisory tor of the Institute for Advanced Study in Princeton, will consult periodically with the investment managers and advise on trends in science. Members of the council include Bruce Hanay, former research vice president at the Bell Laboratories; Reimar Lust, president of Max Planck Gesellschaft; Frank Rauscher Jnr, senior research vice president of the American Cancer Society; Heinrich Ursprung, president of the Swiss Federal Institute of Technology; Itaru Watanabe, professor emeritus at the faculty of medicine at Keio council, headed by Dr Harry Woolf, direc-
University; Chen Ning Yang, Nobel laureate and Albert Einstein professor of physics at the State University of New York, Stony Brook; Horton Stever, former director of the National Science Foundation and president of Carnegie Mellon University and Hideo Itokawa, president of the Systematic Engineering Research Institute.
Each member will receive $\$ 2,500$ a year in fees plus a similar amount for each meeting they attend formally, with an upper limit of $\$ 7,500$ a year. Dr Woolf will be paid an additional $\$ 5,000$. But these earnings will in fact be doubled since they are offered separately by each of the twin funds.

An initial statement by the funds' investment advisers include biotechnology and health care as areas with "superior" investment potential. Other areas included computers, communications, consumer electronics, electronic components and instruments, robotics and office and factory automation.

Peter David

\section{Nature index of biotechnology stocks}

Biogen NV, the company headed by Harvard biologist Walter Gilbert, saw little movement in the price of its shares after going public on 22 March. Its stock was offered at \$23 a share and rose a quarter of a point after 800,000 shares were traded on the first day. By last week its share price had fallen to $201 / 4$.

Biogen's offering contrasted starkly with that of its competitor, Genentech, whose shares soared from $\$ 35$ to $\$ 89$ within hours of the company going public in $\mathbf{1 9 8 0}$. But the contrast came as little surprise (see Nature 10 March, p.101). Had Biogen's shares remained at $\$ 23$ the market value of the company would have reached about $\$ 430$ million, close to 80 per cent of the present value of Genentech, still regarded by Wall Street as the benchmark company.

Market analysts are interpreting the sober reaction to Biogen as a sign that the feverish attitude Wall Street once held towards biotechnology companies has matured. The modest fall in its share prices is not being interpreted as a sign of lack of

\begin{tabular}{|c|c|c|c|c|c|}
\hline $\begin{array}{l}\text { 12-Month } \\
\text { high }\end{array}$ & $\begin{array}{l}\text { 12-Month } \\
\text { low }\end{array}$ & Company & $\begin{array}{l}\begin{array}{l}\text { Close } \\
\text { previous } \\
\text { month }\end{array} \\
\end{array}$ & $\begin{array}{l}\text { Close } \\
25 \text { Mar. }\end{array}$ & Change \\
\hline $603 / 4 *$ & $16 \%$ & A.B. Fortia (Sweden) & 52 & $581 / 4$ & $+6 \frac{1 / 4}{1}$ \\
\hline 8 & 2 & Bio-Logicals (Canada) & $31 / 4$ & $51 / 2$ & $+2 \frac{1}{4}$ \\
\hline 13 & $33 / 8$ & Bio-Response (USA) & $11^{1 / x}$ & 11 & $-1 / 8$ \\
\hline $16 \%$ & $73 / 4$ & Cetus (USA) & $14^{1 / 4}$ & $15 \%$ & $+1 \frac{1}{8}$ \\
\hline $14 \frac{1}{2}$ & $6^{1 / x}$ & Collaborative Research (USA) & $14 \frac{1}{2}$ & $13 \frac{1}{1} 4$ & $-1 \frac{1 / 4}{4}$ \\
\hline $331 / 2 *$ & $53 / 4$ & Damon (USA) & $23^{1 / x}$ & $33^{1 / 2} *$ & $+10^{3} / 8$ \\
\hline $361 / 4 *$ & $81 / 4$ & Enzo-Biochem (USA) & $301 / 4$ & 34 & $+33 / 4$ \\
\hline 28 & $6 \frac{5}{x}$ & Flow General (USA) & $171 / 4$ & $12 \%$ & $-4 \%$ \\
\hline 69 & 26 & Genentech (USA) & $641 / 2$ & $543 / 4$ & $-93 / 4$ \\
\hline $12 \frac{1}{2}$ & $21 / 4$ & Genetic Systems (USA) & $10 \%$ & $10 \frac{1 / 2}{2}$ & $-3 / 8$ \\
\hline $18 \% *$ & 7 & Genex (USA) & $17 \%$ & $171 / 2$ & $-1 / 8$ \\
\hline $273 / 4$ & $9 \%$ & Hybritech (USA) & 27 & 22 & -5 \\
\hline $181 / 2$ & 5 & Molecular Genetics (USA) & $181 / 2$ & $171 / 2$ & -1 \\
\hline 27 & 8 & Monoclonal Antibodies (USA) & $21 \frac{1}{2}$ & $201 / 2$ & -1 \\
\hline $53^{5 / x} *$ & $347 / 8$ & Novo Industri A/S (Den) & $51 \%$ & 51 & $-5 / 8$ \\
\hline
\end{tabular}

The Nature Biotechnology Stock Index for March 1983 stands at 200 compared with 195.1 last month. Base is 100 as of 25 June 1982. The previous index appeared in Nature 10 March, p.101. Close of month prices are the closing prices on the last Friday of each month. Yearly highs and lows are based on Friday trading prices. Where stocks are traded over the counter, the quoted is the bid price. Where stocks are traded on the American and New York stock exchanges, price quoted is the transaction price. Data from E.F. Hutton, Inc.

*New high or low for last 12-month period. 